\title{
Review
}

\section{Primates Can Be a Rallying Symbol to Promote Tropical Forest Restoration}

\author{
Colin A. Chapman a-d Julio Cesar Bicca-Marques ${ }^{\text {e }}$ Amy E. Dunham ${ }^{f}$ \\ Pengfei Fan $^{g}$ Peter J. Fashing ${ }^{\text {h, } s}$ Jan F. Gogarten ${ }^{\text {i-l }}$ Songtao Guo $^{d}$ \\ Michael A. Huffman ${ }^{m}$ Urs Kalbitzer ${ }^{b}$ Baoguo Li $^{d}$ Changyong Mag \\ Ikki Matsuda ${ }^{n}$ Patrick A. Omeja $^{\circ}$ Dipto Sarkar ${ }^{p}$ Raja Sengupta ${ }^{q}$ \\ Juan Carlos Serio-Silvar ${ }^{r}$ Yamato Tsuji ${ }^{m}$ Nils C. Stenseth ${ }^{s}$
}

a Department of Anthropology, Center for the Advanced Study of Human Paleobiology, George Washington University, Washington, DC, USA; ${ }^{\mathrm{b}}$ Department of Anthropology,

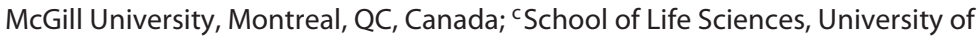
KwaZulu-Natal, Pietermaritzburg, South Africa; ${ }^{d}$ Shaanxi Key Laboratory for Animal Conservation, Northwest University, Xi'an, China; ${ }^{\mathrm{E} E s c o l a ~ d e ~ C i e ̂ n c i a s ~ d a ~ S a u ́ d e ~ e ~ d a ~ V i d a, ~}$ Pontifícia Universidade Católica do Rio Grande do Sul, Porto Alegre, Brazil; ${ }^{\text {fDepartment }}$ of Biosciences, Rice University, Houston, TX, USA; ${ }^{9}$ School of Life Science, Sun Yat-Sen University, Guangzhou, China; ${ }^{\mathrm{h}}$ Department of Anthropology and Environmental Studies Program, California State University Fullerton, Fullerton, CA, USA; 'Epidemiology of Highly Pathogenic Microorganisms, Robert Koch Institute, Berlin, Germany; ${ }^{j}$ Viral Evolution, Robert Koch Institute, Berlin, Germany; ${ }^{k}$ Center for Infection and Immunity, Mailman School of Public Health, Columbia University, New York, NY, USA; 'Institute of Microbiology and Epizootics, Freie Universität Berlin, Berlin, Germany; ${ }^{\mathrm{m}}$ Section of Social Systems Evolution, Primate Research Institute, Kyoto University, Kyoto, Japan; ${ }^{\mathrm{n} C h u b u}$ University Academy of Emerging Sciences, Kasugai-shi, Japan; ${ }^{\circ}$ Makerere University Biological Field Station, Fort Portal, Uganda; ${ }^{\mathrm{P}}$ Department of Geography, Faculty of Arts and Social Sciences, National University of Singapore, Singapore, Singapore; ${ }^{9}$ Department of Geography, McGill University, Montreal, QC, Canada; 'rRed de Biología y Conservación de Vertebrados, Instituto de Ecología AC, Xalapa, Mexico; ${ }^{5}$ Centre for Ecological and Evolutionary Synthesis (CEES), University of Oslo, Oslo, Norway

\section{Keywords}

Conservation · Regeneration · Flagship species · Primate ecology

\section{Abstract}

With $60 \%$ of all primate species now threatened with extinction and many species only persisting in small populations in forest fragments, conservation action is urgently needed. But what type of action? Here we argue that restoration of primate habitat will

karger@karger.com www.karger.com/fpr

(C) 2020 S. Karger AG, Basel

Karger"
Colin Chapman

Department of Anthropology, Center for the Advanced

Study of Human Paleobiology

George Washington University

Washington, DC 20037 (USA)

colin.chapman.research@gmail.com

Baoguo Li

Shaanxi Key Laboratory for Animal Conservation

Northwest University

Xi'an 710069 (China)

baoguoli@nwu.edu.cn 
be an essential component of strategies aimed at conserving primates and preventing the extinctions that may occur before the end of the century and propose that primates can act as flagship species for restoration efforts. To do this we gathered a team of academics from around the world with experience in restoration so that we could provide examples of why primate restoration ecology is needed, outline how primates can act as flagship species for restoration efforts of tropical forest, review what little is known about how primate populations respond to restoration efforts, and make specific recommendations of the next steps needed to make restoration of primate populations successful. We set four priorities: (1) academics must effectively communicate both the value of primates and the need for restoration; (2) more research is needed on how primates contribute to forest restoration; (3) more effort must be put into Masters and PhD level training for tropical country nationals; and finally (4) more emphasis is needed to monitor the responses of regenerating forest and primate populations where restoration efforts are initiated. We are optimistic that populations of many threatened species can recover, and extinctions can be prevented, but only if concerted large-scale efforts are made soon and if these efforts include primate habitat restoration.

() 2020 S. Karger AG, Basel

\section{Introduction}

The world is changing rapidly, and many of these changes negatively affect tropical forests and the primates they support [Kalbitzer and Chapman, 2018] (Fig. 1). Overall, $60 \%$ of all primate species are threatened with extinction [Estrada et al., 2017] (Table 1); approximately $75 \%$ of primate species have declining populations, and $14 \%$ of species are Critically Endangered [IUCN, 2018]. If action is not taken, several species may not persist past the turn of the century. Of particular concern are a number of lemurs, slow lorises, red colobus in general, several gibbon species, and even some great apes [Schwitzer et al., 2015]. While it remains to be confirmed, it seems almost certain that with the disappearance of Miss Waldron's red colobus (Procolobus waldronae) in Africa [Oates et al., 2016], we will have lost the first primate species in the last century. The situation there in West Africa and in China and Madagascar illustrates what can become a global reality. In China, at least three species - the redshanked douc (Pygathrix nemaeus), the white-handed gibbon (Hylobates lar yunnanensis), and the northern white-cheeked gibbon (Nomascus leucogenys) - have been extirpated, and the Hainan (Nomascus hainanus) and Cao-vit gibbons (Nomascus nasutus) will not see the turn of the century without effective conservation action [ $\mathrm{Li}$ et al., 2018]. Orangutans (Pongo spp.) were found throughout much of Southern Asia, including China, as recently as 12,500 years ago, but today occur only in Borneo and

Fig. 1. Changes in human population sizes, agricultural area, and mammalian livestock in primate-range and other countries between the periods 1991-95 and 2011-15. The distribution of extant primates is outlined with dashed, black lines. a Changes in human population sizes. b Changes in the area used for agriculture. c Changes in the number of heads summarized for the most common breeds of mammalian livestock (cattle, sheep, goats, pigs, and buffaloes, which all had at least 194 million heads worldwide in 2014). Data sources are Natural Earth (www.naturalearthdata.com), IUCN Red List mammal shapefile [IUCN, 2018], and FAOSTAT Database [FAO, 2018].

(For figure see next page.) 


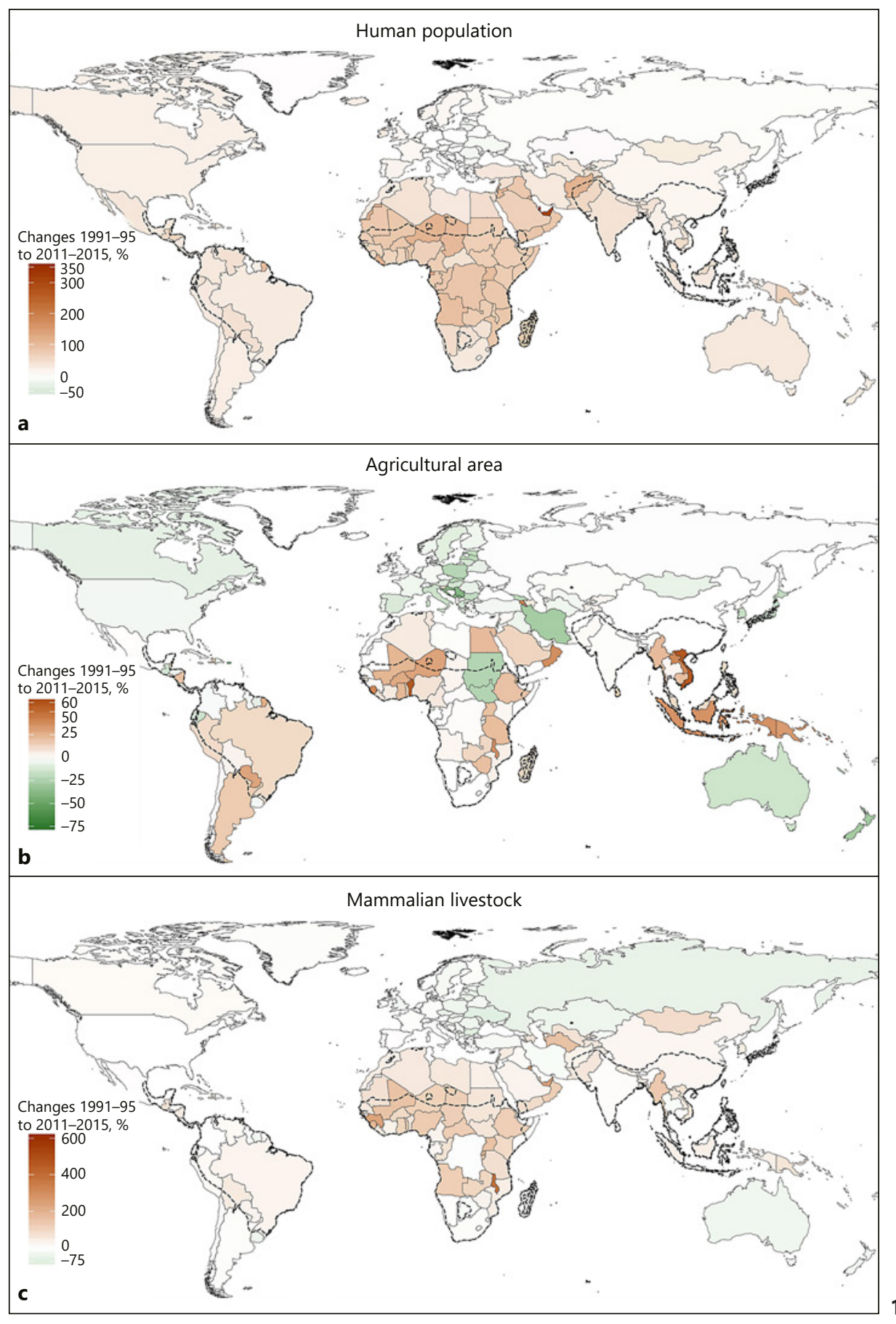

Primates Can Promote Forest Restoration

Folia Primatol 2020;91:669-687 


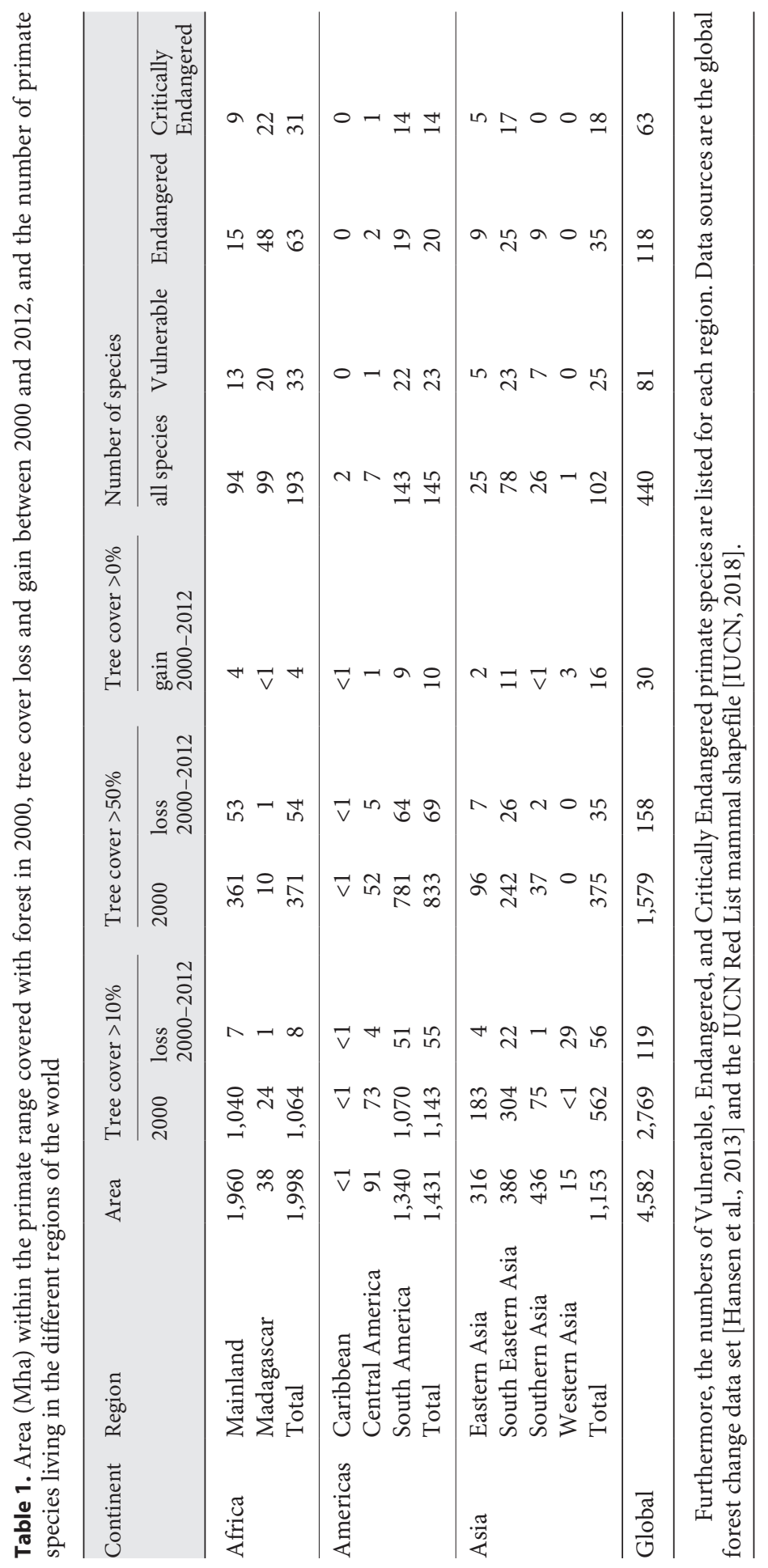


Sumatra where populations are Endangered [Steiper, 2006]. The lemurs of Madagascar represent more than $23 \%$ of the world's primate species, yet $91 \%$ of these species are threatened according to the IUCN. Here deforestation is a particularly acute threat as only 10-20\% of Madagascar's original forest remains [Schwitzer et al., 2014]. With examples such as these, it is clear that action must be taken to conserve the world's primates, but what action and how should academics contribute?

Here we first provide clear examples of why the field of primate restoration ecology is a legitimate field of research and is needed to prevent primate extinctions and to protect endangered populations. Second, we suggest that in many instances primates can make excellent flagship species for restoration efforts, which demonstrates the potential importance of primate restoration ecology. A flagship species is typically a charismatic large vertebrate that can be used to promote a conservation effort because it stimulates public interest and sympathy [Simberloff, 1998]. Third, we review what little is known about how primate populations respond to both passive (simple forest recovery) and active restoration (planting areas with trees) efforts. Finally, we make specific recommendations as to the most critical steps that need to be taken to make restoration of primate populations successful. To meet these objectives, we gathered a global team of academics with experience in restoration efforts so that we could provide a more complete and global perspective on primate restoration ecology. We have intentionally used the term "primate restoration ecology" as this needs to be considered a distinct subfield of ecology and conservation. Restoring an animal population draws on different theories (e.g., population regulation) and tools and approaches (e.g., nutritional ecology) than the subfield of forest restoration. For example, restoring a primate population might involve intentionally planting tree species that meet the nutritional needs of a critically endangered primate or planting corridors among fragments in such a way as to minimize the potential of disease spread.

We contend that conservation efforts should focus first on the conservation and protection of the old-growth forests for which most primate species are adapted. These forests harbor high levels of biodiversity that is often relatively rare and can only be regained after hundreds of years, if at all. Thus, the protection of remaining old-growth forests must be a priority. From this perspective, restoration should be viewed as an unavoidable, but often necessary, remedy to a bad situation that humans have created. Restoration should only be used when populations do not have a sufficient area of habitat remaining, when it can be combined with conservation of oldgrowth forest to better the conditions for threatened populations (e.g., connecting corridors), or when opportunities arise to easily regain forest area from degraded habitats (e.g., carbon offset projects). The fact that regenerating forests are suitable for many primates should never be used in arguments to deforest areas, as this will lead to a general loss of biodiversity on the large scale.

We fully recognize that restoring habitats alone will not be sufficient and that restoration will not work in all areas or with all cultures. Rather, we present the case that restoration of habitats will be a critical component of a multidimensional approach that must also deal with hunting, cultural perspectives of primates, and potential issues of conflict between restoration efforts and local community interests, including crop raiding. We do not attempt to deal with all issues that must be considered given that they are typically dependent on specifics of the setting, but rather focus on generalities of primate restoration ecology. 


\section{Why Is the Field of Primate Restoration Ecology Needed?}

Land use change is the greatest threat to biodiversity in the tropics [Pimm et al., 2014] and is causing the extirpation and endangerment of many populations [Dirzo et al., 2014]. In 2015, less than half of the world's tropical forests remained [Lewis et al., 2015] and between 2000 and 2012, 2.3 million $\mathrm{km}^{2}$ of forest were lost globally and the loss in the tropics increased by $3 \%\left(2,101 \mathrm{~km}^{2}\right)$ a year [Hansen et al., 2013]. To put this in perspective, an area approximately the size of the Democratic Republic of Congo was lost in 12 years, or an area larger than the islands of New Guinea, Borneo, and Madagascar combined. Of the tropical forest that remains, nearly half is already degraded [Lewis et al., 2015; Chazdon and Guariguata, 2016]. These degraded forests are increasingly being converted to plantations of oil palm, pine, rubber, and eucalyptus trees [Linder, 2013; Azhar et al., 2014]. Globally, governments are allowing this destruction to happen despite the fact that 500 million people are dependent on tropical forests for their survival [Chomitz, 2007].

The primary habitat of primates is tropical forest, and therefore it is not surprising that large parts of the extant primate distribution are covered by dense forest (Fig. 2a). According to the global forest change data set [Hansen et al., 2013], around 15.8 million $\mathrm{km}^{2}$ within the primate range were covered by dense forest in 2000 (more than $50 \%$ canopy density; Africa: 3.71 million $\mathrm{km}^{2}$, Americas: 8.3 million km², Asia: 3.75 million $\mathrm{km}^{2}$; Table 1). Forest degradation, however, is apparent throughout the primate range (Fig. $2 \mathrm{~b}$ ). It is estimated that $10 \%$ of the area covered with dense forest in 2000 was lost by 2012 (Africa: 0.5 million $\mathrm{km}^{2}$; Americas: 0.7 million km²; Asia: 0.3 million $\mathrm{km}^{2}$ ).

Many degraded forests occur in small fragments that cannot support many mammal and bird populations over the long term [Chapman et al., 2013]. In fact, globally intact forest landscapes (a continuous mosaic of forest and naturally treeless areas larger than $500 \mathrm{~km}^{2}$ with no remotely detected signs of human activity) comprise only $20 \%$ of remaining tropical forest, and these forests are disappearing at a rate of $7.2 \%$ annually [Potapov et al., 2017]. Only $12 \%$ of these intact forest landscapes are protected [Potapov et al., 2017]. Furthermore, it is predicted that in the next 50 years there will be a 33-fold increase in the number of fragments and the mean size of these fragments will be between 0.25 and 17 ha [Taubert et al., 2018]. Unfortunately, many primate species are now only found in fragmented forest. For example, a recent analysis of 22 of the 27 primate species in China suggests that 15 of these species have less than 3,000 individuals, with all living in forest fragments [Estrada et al., 2017; Chapman, 2018; Li et al., 2018].

This forest loss and fragmentation is clearly driven by increasing human populations and high consumption rates [Crist et al., 2017; Kalbitzer and Chapman, 2018]. The world's population is expected to rise from 7 billion in 2011 to almost 10 billion in 2050 [United Nations, 2009]. Such growth does not occur uniformly, and many tropical countries are undergoing particularly rapid human population growth (Fig. 1a) that is coupled with strong economic growth. With this economic prosperity, there is a tendency for people to eat higher on the food chain (e.g., beef cattle) leading to even greater habitat loss. Globally, agricultural lands expanded by 48,000 $\mathrm{km}^{2}$ between 1999 and 2008 [Phalan et al., 2013] - an area slightly less than the size of Costa Rica. It is estimated that with current agricultural practices an additional 1 billion ha of agricultural land - an area larger than Canada - will be needed to meet 


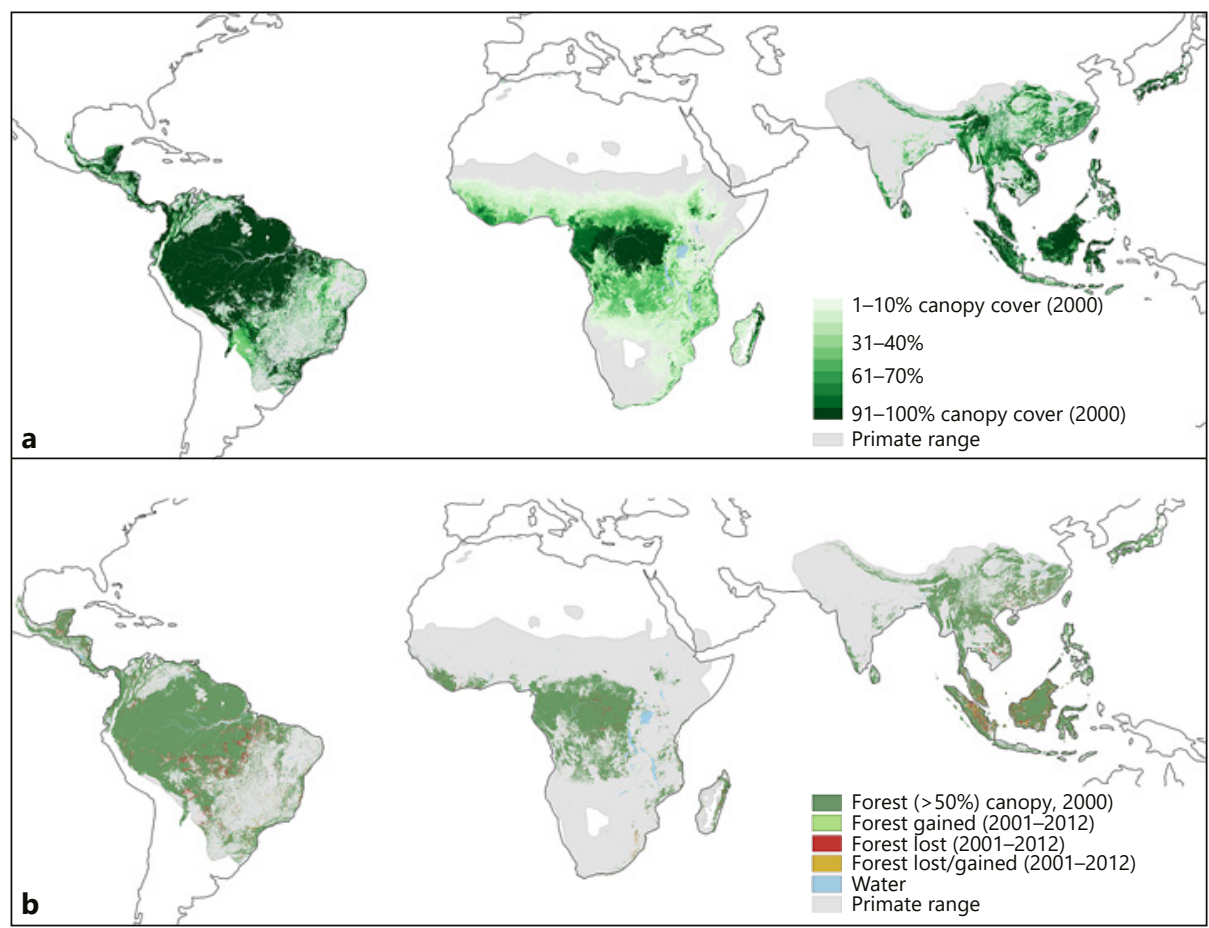

Fig. 2. Tree canopy cover and changes in canopy cover within the distribution of extant primates. a Tree canopy cover in the year 2000. The green shades illustrate the percentage of area within each cell covered by closed canopy for all vegetation taller than $5 \mathrm{~m}$ in height. b Area covered by vegetation with canopy closure of more than $50 \%$ in 2000, and areas where loss, gain, or loss and gain was detected in the years 2001-2012. Loss is only shown for pixels that had a canopy closure of $>50 \%$ in 2000, whereas gain are areas where the area changed from nonforest to forest, independent of percentage canopy closure. Data taken from the global forest change data set (http:// earthenginepartners.appspot.com/science-2013-global-forest; see Hansen et al. [2013]). To see more details, zoom into the map or look at the Global Forest Watch webpage (https://www.globalforestwatch.org/).

the demands of the growing human population in 2050 [Laurance et al., 2014]. Agricultural land expanded much faster in tropical countries than in other countries over the last 20 years (Fig. 1b).

In addition, climate change will pose a significant threat to tropical forest, but this threat is poorly understood. Understanding and mitigating the impacts of climate change will be one of the greatest challenges facing primate conservationists in the coming decades. There are disagreements among climate models about the exact magnitude of changes to expect, but these models predict that approximately $70 \%$ of seasons in the tropics will exceed the temperature maxima of the late 20th century between 2010 and 2039 [Diffenbaugh et al., 2011].

These statistics present a very grim picture for primate conservation. Fortunately, deforested land does not always have to remain deforested. With increasing ur- 
banization, many people are moving off previously deforested land and many areas are regenerating to secondary forest [Wright and Muller-Landau, 2006; Jacob et al., 2008]. In fact, the UN Population Division estimates that $90 \%$ of the world's population growth between 2000 and 2030 will occur in cities of the developing world [United Nations Population Division, 2008], and much of this growth will be in countries with primates [Kalbitzer and Chapman, 2018]. As a result of urbanization, throughout the tropics, secondary forests now cover substantial areas. In fact, for over a decade the area covered by secondary forests has exceeded the area covered by primary forests in most countries [FAO, 2005, 2016]. It is estimated that in the 1990s, secondary forests replaced at least 1 of every 6 ha of primary forest which was deforested [Wright and Muller-Landau, 2006]. Secondary forests represent more than 35\% of all remaining tropical forests [Emrich et al., 2000; Chazdon and Uriarte, 2016]. Consequently, more than 1 billion ha of degraded forest and woodlands in the tropics could be used in restoration efforts [FAO, 2010; Laestadius et al., 2011]. Abandonment of land often occurs because the soil nutrients become depleted and crop yields decrease, pushing agriculturalists to cut down more forest or move to the cities. This is particularly the case in Africa where up to $93 \%$ of deforestation occurs because of shifting agriculture [Curtis et al., 2018]. It is slightly counterintuitive that there are increasing amounts of degraded, often unused, land, while at the same time estimates of the amount of land required to support the world's growing human population rise. This appears to be a result of the fact that much of the land, particularly in Africa, is used inefficiently. What is needed is for farmers to have better access to existing knowledge and technology [Laurance et al., 2014]. The fact remains that a large proportion of the Earth's tropical forest is already cleared degenerated/regenerated forest and this area can be used for restoration projects.

Evaluating these trends suggests that the window of opportunity to use these lands for restoration is limited as the rate of conversion of degraded forests to industrial plantations is rapidly increasing in the tropics. For example, conversion to oil palm production was responsible for 3 million ha of deforestation between 2000 and 2011 (an area the size of the Philippines) [Vijay et al., 2016] and cacao production accounted for between 2 and 3 million ha between 1988 and 2008 [Kroeger et al., 2017]. Also, more land is projected to be needed for agricultural activities because of human population growth and more people eating higher on the food chain (Fig. 1a, c). Thus, farmers will increasingly reuse degraded land for food crops or cattle grazing. But this is also the time when people have options for where on the food chain they select their diet, whether or not to get improved technology to rural farmers, and whether or not to use products containing palm oil or other products that are associated with deforestation. Thus, it is the opinion of the authors, who live and/or work in many of the important tropical regions, that now is the time to identify and promote restoration as a major conservation strategy.

\section{Primates as Flagship Species in Restoration Projects}

Primates can be used as flagship species [Simberloff, 1998] to promote public interest and raise sympathy and funding for restoration efforts. In the past, primates have repeatedly been used as flagship species to promote conservation projects and to protect areas from deforestation or poaching [Lammertink et al., 2003; Cheyne, 
2009; Strier, 2010; Xiang et al., 2011; Strier et al., 2017], with the apes playing a particularly important role in these efforts [Williams et al., 2000; Marshall et al., 2016]. The presence of great ape research and the potential of associated ecotourism played significant roles in the creation of parks, such as Gombe and Mahale in Tanzania and Kibale, Bwindi, and Mgahinga Gorilla National Park in Uganda. Without using gorillas and chimpanzees as flagship species, some of these parks would not exist today. The use of the flagship species approach must consider the target audience and its purpose (e.g., community outreach or fund raising in wealthy nations). Often the perspectives of the local community are very different than those of the international community. For example, it is clear that the use of chimpanzees to promote conservation awareness and fund raising has been very successful in North America and Europe. The success of the Jane Goodall Institute illustrates this fact. In contrast, in many communities in Africa chimpanzees are disliked as they raid crops [NaughtonTreves et al., 1998] and are known to kill children [Wrangham et al., 2000]. Restoration ecologists, who are typically ecologically and botanically oriented researchers, are, for the most part, missing a big opportunity by failing to pay enough attention to primates. Similarly, primatologists, who are typically behaviorally oriented researchers, are generally missing an important conservation opportunity by failing to make their voices heard in the international forest restoration arena and with carbon offset groups. Here we consider restoration initiatives to include both those that plant seedlings and young trees of a variety of native species, or protect areas from disturbances, particularly fire [Omeja et al., 2011b] and facilitate the growth of a species-rich plant community. We do not consider those instances that consist of planting seedlings or young trees of a single species or very few species that have an important economic value (e.g., eucalyptus, oil palm, or pine), but typically have a limited value for wildlife [Omeja et al., 2011a; Estrada et al., 2012].

Primates are good flagship species for several reasons, one being that, like many other mammals and birds, the current conservation situation for primates is grim. Overall, $60 \%$ of all primate species are threatened with extinction [Estrada et al., 2017] (Table 1). The situation in China and Madagascar illustrates what can become a global reality. Similarly, in South America $36 \%$ of the primate species are threatened, and many of these species have been or could be used as flagship species (e.g., yellowtailed woolly monkey - Lagothrix flavicauda, golden lion tamarin - Leontopithecus rosalia, muriquis - Brachyteles hypoxanthus and B. arachnoides) [Strier, 2010; IUCN, 2018]. Thus, as primates are so endangered it is generally legitimate to argue for restoration efforts to enlarge fragments or parks or to create conservation corridors. This in turn will help the larger goal of promoting biodiversity recovery.

Furthermore, primates are good flagship species when new habitat is needed to respond to climate change. The rationale for advocating primates as flagship species with respect to climate change is that a great deal of information is becoming available from long-term primate research sites that quantify the cascading effects of climate change on these charismatic animals [Altmann et al., 2002; Chapman et al., 2017; Strier et al., 2017; Kalbitzer and Chapman, 2018]. Climate change will not only influence the extent of available habitat; it will influence the trees in the remaining forests that provide food resources to animals. It is clear that climate change will impact the phenology of tropical forests, but the exact nature of that impact remains uncertain [Chapman et al., 2005; Polansky and Boesch, 2013; Chapman et al., 2018c; Wright and Calderón, 2018]. This uncertainty is partially a result of the fact that past 
research on how changing climate patterns have altered phenological responses has focused on the community level (i.e., many plant species analyzed for a single response), whereas animals respond to the availability of important foods. New research is revealing that each tree species responds in dramatically different ways to changes in climate (C.A. Chapman, unpubl. data - Africa, S.J. Wright, unpubl. data - Central America). Since different primates often rely on different plant resources, predicting the future of any single species will prove very difficult. This simply calls for a greater research effort and some of the needed data are already available from many long-term primate research sites, but a network of researchers has not coalesced.

In general, it is relatively easy to imagine that in areas becoming hotter and drier, food trees will die, and drought events will have devastating effects. This expectation is supported by data from Amboseli National Park, Kenya, where the average daily maximum temperature increased by $0.275^{\circ} \mathrm{C}$ per year between 1976 and 2000 (an order of magnitude greater than climate change models predicted [Altmann et al., 2002]). This increase contributed to a dramatic loss of tree cover affecting primate populations [Altmann et al., 2002]. What will happen to tropical forests where the climate becomes wetter is not clear. For example, Kibale National Park, Uganda (hereafter Kibale), has experienced changes in climate that are more extreme than global averages. Rainfall has gradually increased over the last $100+$ years, so that by 2017 , the area received $345 \mathrm{~mm}$ more rainfall per year than in 1900 . Furthermore, the average maximum monthly temperature has increased by $4.5^{\circ} \mathrm{C}$ in the last 40 years [Chapman et al., 2018c]. Correspondingly, a number of tree species have stopped fruiting [Chapman et al., 2005], meaning that there is less fruit available for the frugivores. For example, Trilepisium madagascariense has stopped fruiting at a site in the north of the park but continues to fruit at a site to the south where it is drier because of a natural north-south decline in rainfall [Chapman et al., 2005]. The variability in the timing of rainfall is also expected to occur, altering wet and dry seasonality [Stampone et al., 2011] and the effects of this variability in food resources on wildlife are largely unknown. Climate change can also negatively affect food quality. Climate change corresponds with an increase in fiber and a decrease in protein in leaves in Kibale [Rothman et al., 2015]. Given that many colobus monkeys exhibit selection for leaves with a high protein and low fiber content [Chapman et al., 2002], declining leaf quality would be expected to have a major impact on their populations. In fact, a $31 \%$ decline in colobine abundance is predicted based on a model between colobine biomass and the protein-to-fiber ratio of the mature leaves [Chapman et al., 2004]. However, illustrating our incomplete understanding of such systems, the predicted decline has not happened; in fact, colobine populations have increased [Chapman et al., 2018a]. Further work on the impact of climate change on food quality and primate abundance at more sites is clearly needed.

\section{How Do Primate Populations Respond to Restoration Efforts?}

Not surprisingly, the responses of primates to restoration are dependent on the type of disturbance and the species involved. Many studies have examined how primates respond to logging, and although some folivores can benefit from logging, it generally leads to population declines [Meijaard et al., 2005; Guo et al., 2008; Chap- 
man et al., 2010]. However, the speed with which primate populations rebound after logging varies tremendously among locations and species and some populations do not recover even after more than half a century [Chapman et al., 2018a]. Therefore, despite the efforts made to date, considerable research is still needed to understand variation in recovery rates. This information is needed for the construction of management plans for the many species that will be affected by the large areas currently sold as logging concessions. In the major forest blocks supporting primates, 750,000 $\mathrm{km}^{2}$ of forestland are under concession to timber companies [Yale School of Forestry, 2018], an area approximately the size of Turkey. However, since recovery of primate populations following logging has been extensively reviewed [Johns, 1992; Meijaard et al., 2005; Brodie et al., 2015; Osazuwa-Peters et al., 2015], we will not explore this further here.

In contrast to the many studies of the effect of logging on primate populations, only a handful of studies examine the response of primate communities to forest regeneration from agricultural or pastoral land [Andresen et al., 2018]. The studies that do address this generally indicate that forests, and the primate communities they support, can rebound quickly when left to recover or are encouraged to recover. For example, Baya and Storch [2010] surveyed a former village site in Korup National Park, Cameroon, that had been abandoned for 8 years and found thriving populations of all 8 species of diurnal primates that occur in the region. In addition, sighting frequency in this recovering area was not significantly different from other sectors of the park. Successional forests in Sierra Leone aged 5-12 years were used more than expected by 4 of 7 primates studied [Fimbel, 1994]. Seven years after a mosaic of abandoned agricultural land and grassland in Uganda had been replanted with trees as part of a carbon offset program [Omeja et al., 2012; Wheeler et al., 2016], all local species of diurnal primates were present in high numbers, including the endangered red colobus (Piliocolobus tephrosceles) and chimpanzee (Pan troglodytes). Furthermore, 19 years after planting, all 6 primate species, except mangabeys (Lophocebus albigena), had densities in the restored area that were equal to those in the neighboring old-growth forest [Chapman et al., 2018a, b]. In the 1930s and 1940s, at least 6 economically valuable tree species were planted in a $2-\mathrm{km}^{2}$ clearing adjacent to a large old natural forest at Kakamega Forest, Kenya [Fashing et al., 2012]. The planted area was then left to regenerate naturally with additional tree species arriving from the neighboring natural forest. Censuses conducted between 2006 and 2010 found that while primate densities were $35-46 \%$ lower in planted forest than natural forest, the same three diurnal primate species which inhabit the natural forest (Cercopithecus ascanius, C. mitis, Colobus guereza) also occurred in the planted forest [Fashing et al., 2012].

The fact that most species studied to date appear capable of inhabiting a combination of natural and planted forest provides hope for the future. Furthermore, despite the fact that there are few data on how primate populations change as forests regenerate, descriptions of how a forest community develops and changes suggest that when there is a nearby or connected healthy source population, primates will readily colonize the regenerating forest [Holl and Aide, 2011; Omeja et al., 2012]. Given the high nutritional value of the tree species that first grow after disturbance [Coley, 1983; Omeja et al., 2016], regenerating forests can provide a great opportunity to help expand the size of threatened populations of primates.

We know of, or are involved in, several forest restoration projects designed, at least partially, to promote the recovery of primate populations, though many of these 
projects were initiated for their potential conservation gains, and thus have not led to publications. This is a shame, as it is very beneficial for the conservation community to learn from the successes and failures of such projects. For example, a project in Uganda found that while it seemed logical to remove tall grasses (i.e., 2-3 m) away from planted seedlings to decrease resource competition and shading, doing so led to soil desiccation and increased seedling mortality in the dry season [Omeja et al., 2009; Face the Future, 2011].

Examples of primate restoration projects include the following. The Cao-vit gibbon (Nomascus nasutus) is a Critically Endangered species, with only one tiny population of 110-120 individuals living in a small karst forest patch along the ChinaVietnam border [Fan, 2012]. Starting in 2011 in Vietnam, food trees were planted in abandoned cultivation fields ( 32.3 ha in six valleys), while in China pilot habitat rehabilitation efforts were initiated in 2012 at four sites covering $1.3 \mathrm{ha}$. It is too soon to know what the impact of these restoration efforts will be. In southeast Mexico, efforts have been made to connect forest fragments for primates. Tree planting is greatly facilitated by at least 20 artisan groups ( +350 women) that sell handicrafts, often depicting monkeys, and part of the profit goes to restoration efforts, and by schools that grew seedlings and then planted forest corridors. There have been reforestation efforts along the borders of Ranomafana National Park, Madagascar, since 2006 with a primary focus on lemur conservation. The project involves cooperation with schools and villages to create corridors between forest patches. Another example comes from the Qinling Mountains in central China, an area of vital habitat for the Endangered golden snub-nosed monkeys (Rhinopithecus roxellana). Since 2005 more than 101,600 saplings were planted by approximately 2,400 students from Northwest University and local schools to restore over 120 ha. This management has succeeded, as the golden snub-nosed primate population is recovering. Since 2017, in Uttrakhand State of India, the planting of seedlings, of species used by langurs as sleeping sites and humans for livestock fodder, in the forests around high-altitude subsistence farming communities has begun with the help of groups of village women and school children.

\section{Necessary Next Steps}

Given the need for restoration, particularly in the face of climate change, growing human populations, the number of primate species that are threatened, the extent of tropical deforestation, and the amount of carbon dioxide already released into the atmosphere, it is clear that a great deal must change, and that change must occur soon and on a large scale. We see four priorities.

(1) Promote awareness and action: for the field of primate restoration ecology to become an important component of conservation strategies on the needed scale, academics must communicate both the value of primates and the need for restoration to the affected local communities, the general public globally, and to policy makers. It is only by convincing the public and government of the value of primates and the forests that support them that funding will be made available to initiate restoration projects on the needed scale.

(2) Research: a great deal of research is needed given the paucity of data on primate restoration ecology and the fact that tree community regeneration and primate population responses are likely to be highly spatially variable. One of the primary 
questions that needs to be addressed is under what conditions do primates contribute to restoration efforts through their seed dispersal abilities. Thus, it will be important to consider the pool of primate seed dispersers that will use grassland, secondary forests, and abandoned agricultural land. Testing whether specific interventions, such as planting certain plant species to attract primates into secondary areas, represents an exciting field of research [Jacob et al., 2016].

A second critically important set of questions that requires extensive research deals with what seeds primates disperse into the areas being restored and the fate of these seeds at least up to the sapling stage [Tsuji and Su, 2018]. The quantity and diversity of fruits eaten by most primates make them potentially very important for restoring a diverse forest community. However, the disappearance/mortality rate of seeds in primate dung is typically high (often 75-100\%) and postdispersal events can reverse or eliminate patterns established at the initial stages of seed dispersal [Balcomb and Chapman, 2003].

The motivation that the Paris Agreement created to combat climate change and the refinement of the mechanisms to sequester carbon in the REDD+ programs are opportunities that must not be missed if the scientific community is to promote primate conservation. Accepting this statement highlights the need for research into the extent to which primates contribute to carbon sequestration in the landscapes designated for restoration for primate conservation.

In many cultures, but not all, primates are viewed positively [Nahallage and Huffman, 2013], thus they provide an access point to involve local communities in conservation and conduct research into the human dimensions of conservation. Research can address how to best involve communities and how involvement changes attitudes and levels of illegal encroachment [Jacobson, 2010; Kirumira et al., 2019].

(3) Training: in the tropics, conservation research is often regarded as a low priority given the unmet needs of people, lack of technical capacity in government agencies, insufficient funding, inadequate infrastructure, and, in many instances, lack of collaboration among local scientists and members of the international community [Atickem et al., 2019; Kühl et al., submitted]. Many tropical countries have rapidly growing economies but lack the scientific and technological capacity needed to translate rapid economic growth into the type of sustainable development that could promote tropical forest conservation and restoration. Owing to massive differences in funding, student-staff ratios, and access to facilities [Teferra, 2013], education in much of the tropics does not provide Masters and $\mathrm{PhD}$ students as rigorous a background as students receive in most high-income countries. As a result, more funding and effort must be put into Masters and $\mathrm{PhD}$ training in countries with tropical forests. It is our opinion that the universities of higher-income countries have largely failed to provide the atmosphere that would encourage their professors to invest their limited energy and resources in the training of Masters and PhD students from countries that are the home of most primates. Thus, it is well past time that the reward system of universities in higher-income countries changes to meet the reality of a global society [Chapman and Peres, 2001; Atickem et al., 2019]. Working conditions must also change in tropical countries. For instance, the pay for professors in countries supporting tropical forests is typically abysmal [UNESCO, 2010]; as little as USD 300-500 per month at even the best universities. Without improved working conditions, the brain drain of the talent needed to construct and manage the required large- 
scale restoration projects will continue [UNESCO, 2010]. In 2001, it was estimated that $30,000 \mathrm{PhD}$ holders of African descent were living and working outside their home countries; this number exceeds the total number of African-born scientists with PhDs working in Africa [Hassan, 2001].

(4) Long-term research and monitoring: while it may seem obvious, we wish to emphasize the need to monitor plant community and primates' responses to restoration. Many, if not most, conservation projects are not monitored using rigorous methods, over a sufficiently long duration, to be able to evaluate the projects' successes and failures. With restoration projects aimed to help threatened populations to recover, we suggest this evaluation should involve a minimum of a decade of research. This long evaluation is needed because first the tree community must become established and grow, and then the longer-lived primates must respond. It is ironic that at a time when there is such a clear need for effective restoration, funding for long-term research is becoming increasingly difficult to obtain [Chapman et al., 2017; Hayes and Carsten, 2017].

It is critical in this evaluation that methods are standardized so that comparisons can be made among species, habitats, geographical regions, and restoration methods. Again, this statement might seem obvious, but even after decades of testing, no agreement has been reached on the best methods for censusing primate populations, and disparity in estimates based on different methods can exceed $400 \%$ [Chapman et al., 2010]. Without employing similar methods across time, changes cannot be evaluated. For evaluating changes in primate numbers, it has been suggested that the simplest approach is to always report groups seen per kilometer walked [Chapman et al., 2018a] and while this might not be the final technique to be agreed upon, it is a step in the right direction, especially if presented along with more complex measures of density.

In 1962, before almost all of the authors of this paper were born, François Bourlière wrote: "Unfortunately, at the very moment when we are becoming aware of the uniqueness of the Primates..., we are also realizing how precarious is the future of the Primates and to what point competition with industrial man is threatening their survival ... Can we remain unmoved at such annihilation?” [Bourlière, 1962, p. 185]. Since this statement was made, the situation has only gotten much worse. This suggests that it is only with a great deal of effort from many highly motivated individuals that society will overcome the inertia of maintaining the status quo so that we will not bear witness to the extinction of primate species before the next century.

\section{Acknowledgements}

We would like to thank all the people we have worked with, both academic friends and local community members that have shaped the thoughts that we present here.

\section{Disclosure Statement}

The authors have no ethical conflict or conflicts of interest to disclose. 


\section{Funding Sources}

Colin Chapman would like to thank the Humboldt Foundation for providing the time to develop some of these ideas and the IDRC grant "Climate change and increasing human-wildlife conflict" which helped fund some of his recent work on restoration. Jan Gogarten was supported by the German Academic Exchange Service (DAAD) with funds from the German Federal Ministry of Education and Research (BMBF) and the People Programme (Marie Curie Actions) of the European Union's Seventh Framework Programme (FP7/2007-2013) under REA grant agreement No. 605728 (PRIME - Postdoctoral Researchers International Mobility Experience).

\section{Author Contributions}

Colin Chapman conceived of the general idea of this manuscript and brought together the global team of researchers to address the idea. Colin Chapman and Nils C. Stenseth designed the study. All authors contributed to the ideas that we present and helped in drafting the article and revising its content. Urs Kalbitzer created the figures and the table. Different authors contributed descriptions of restoration projects globally: Colin Chapman and Patrick Omeja - the carbon offset project in Kibale National Park, Uganda; Pengfei Fan and Changyong Ma - the Cao-vit gibbon (Nomascus nasutus) along the Chinese-Vietnam border; Juan Carlos Serio-Silva - the community conservation efforts in Mexico; Amy Dunham - the restoration around Ranomafana National Park, Madagascar; Baoguo Li and Songtao Guo - the restoration projects for the endangered snub-nosed monkeys in the Qinling Mountains, China; and Michael Huffman - the community restoration project in Uttrakhand State, India. All authors approve the final version of the paper.

\section{References}

Altmann J, Alberts SC, Roy SB (2002). Dramatic change in local climate patterns in Amboseli basin, Kenya. African Journal of Ecology 40: 248-251.

Andresen E, Arroyo-Rodríguez V, Ramos-Robles M (2018). Primate seed dispersal: old and new challenges. International Journal of Primatology 39: 443-465.

Atickem A, Stenseth NC, Fashing PJ, Nguyen N, Chapman CA, Bekele A, Mekonnen A, Omeja PA, Kalbitzer U (2019). Build science in Africa. Nature 570(7761): 297-300.

Azhar B, Lindenmayer DB, Wood J, Fischer J, Zakaria M (2014). Ecological impacts of oil palm agriculture on forest mammals in plantation estates and smallholdings. Biodiversity and Conservation 23: 11751191.

Balcomb SR, Chapman CA (2003). Bridging the gap: influence of seed deposition on seedling recruitment in a primate-tree interaction. Ecological Monographs 73: 625-642.

Baya L, Storch I (2010). Status of diurnal primate populations at the former settlement of a displaced village in Cameroon. American Journal of Primatology 72: 645-652.

Bourlière F (1962). The need for a new conservation policy for wild primates. Annals of the New York Academy of Sciences 102: 185-189.

Brodie JF, Giordano AJ, Zipkin EF, Bernard H, Mohd-Azlan J, Ambu L (2015). Correlation and persistence of hunting and logging impacts on tropical rainforest mammals. Conservation Biology 29: $110-121$.

Chapman CA (2018). A road for a promising future for China's primates: the potential for restoration. Zoological Research 39: 244-248.

Chapman CA, Peres CA (2001). Primate conservation in the new millennium: the role of scientists. Evolutionary Anthropology 10: 16-33.

Chapman CA, Bortolamiol S, Matsuda I, Omeja PA, Paim FP, Reyna-Hurtado R, Sengupta R, Valenta K (2018a). Primate population dynamics: variation in abundance over space and time. Biodiversity and Conservation 27: 1221-1238.

Chapman CA, Chapman LJ, Bjorndal KA, Onderdonk DA (2002). Application of protein-to-fiber ratios to predict colobine abundance on different spatial scales. International Journal of Primatology 23: $283-310$

Primates Can Promote Forest Restoration

Folia Primatol 2020;91:669-687 
Chapman CA, Chapman LJ, Naughton-Treves L, Lawes MJ, McDowell LR (2004). Predicting folivorous primate abundance: validation of a nutritional model. American Journal of Primatology 62: 55-69.

Chapman CA, Chapman LJ, Struhsaker TT, Zanne AE, Clark CJ, Poulsen JR (2005). A long-term evaluation of fruiting phenology: importance of climate change. Journal of Tropical Ecology 21: 31-45.

Chapman CA, Corriveau A, Schoof VAM, Twinomugisha D, Valenta K (2017). Long-term primate research and its significance for developing theory and conservation plans. Journal of Mammalogy 98: 652-660.

Chapman CA, Ghai RR, Jacob AL, Koojo SM, Reyna-Hurtado R, Rothman JM, Twinomugisha D, Wasserman MD, Goldberg TL (2013). Going, going, gone: a 15-year history of the decline of primates in forest fragments near Kibale National Park, Uganda. In Primates in Fragments: Complexity and Resilience (Marsh LK, Chapman CA, eds.), pp 89-100. New York, Springer.

Chapman CA, Omeja PA, Kalbitzer U, Fan P, Lawes MJ (2018b). Restoration provides hope for faunal recovery: changes in primate abundance over 45 years in Kibale National Park, Uganda. Tropical Conservation Science 11: 1940082918787376.

Chapman CA, Struhsaker TT, Skorupa JP, Snaith TV, Rothman JM (2010). Understanding long-term primate community dynamics: implications of forest change. Ecological Applications 20: 179-191.

Chapman CA, Valenta K, Bonnell TR, Brown KA, Chapman LJ (2018c). Solar radiation and ENSO predict fruiting phenology patterns in a 16-year record from Kibale National Park, Uganda. Biotropica 50: 384-395.

Chazdon RL, Guariguata MR (2016). Natural regeneration as a tool for large-scale forest restoration in the tropics: prospects and challenges. Biotropica 48: 716-730.

Chazdon RL, Uriarte M (2016). Natural regeneration in the context of large-scale forest and landscape restoration in the tropics. Biotropica 48: 709-715.

Cheyne SM (2009). Challenges and opportunities of primate rehabilitation - gibbons as a case study. Endangered Species Research 9: 159-165.

Chomitz KM (2007). At Loggerheads? Agricultural Expansion, Poverty Reduction, and Environment in the Tropical Forests. Washington, World Bank.

Coley P (1983). Herbivory and defensive characteristics of tree species in a lowland tropical forest. Ecological Monographs 53: 209-233.

Crist E, Mora C, Engelman R (2017). The interaction of human population, food production, and biodiversity protection. Science 356: 260-264.

Curtis PG, Slay CM, Harris NL, Tyukavina A, Hansen MC (2018). Classifying drivers of global forest loss. Science 361: 1108-1111.

Diffenbaugh NS, Ashfaq M, Scherer M (2011). Transient regional climate change: analysis of the summer climate response in a high-resolution, century-scale ensemble experiment over the continental United States. Journal of Geophysical Research: Atmospheres 116: D24111.

Dirzo R, Young HS, Galetti M, Ceballos G, Isaac NJB, Collen B (2014). Defaunation in the Anthropocene. Science 345: 401-406.

Emrich A, Pokorny B, Sepp C (2000). The Significance of Secondary Forest Management for Development Policy. Eschborn, GTZ.

Estrada A, Garber PA, Rylands AB, Roos C, Fernandez-Duque E, Di Fiore A, Nekaris KAI, Nijman V, Heymann EW, Lambert JE (2017). Impending extinction crisis of the world's primates: why primates matter. Science Advances 3: e1600946.

Estrada A, Raboy BE, Oliveira LC (2012). Agroecosystems and primate conservation in the tropics: a review. American Journal of Primatology 74: 696-711.

Face the Future (2011). Face the Future - Kibale National Park. Wageningen, Face the Future.

Fan P (2012). Taxonomy and conservation status of gibbons in China. Acta Theriologica Sinica 32: 248258.

FAO (2005). Global Forest Resources Assessment 2005: Progress towards Sustainable Forest Management. FAO Forestry Paper 147. Rome, Food and Agriculture Organization of the United Nations.

FAO (2010). Global Forest Resource Assessment 2010. Rome, Food and Agriculture Organization of the United Nations.

FAO (2016). Global Forest Resources Assessment 2015: How Are the World's Forest Changing? Rome, Food and Agriculture Organization of the United Nations.

FAO (2018). FAOSTAT production statistics. http://faostat.fao.org/default.aspx (December 2018).

Fashing PJ, Nguyen N, Luteshi P, Opondo W, Cash JF, Cords M (2012). Evaluating the suitability of planted forests for African forest monkeys: a case study from Kakamega Forest, Kenya. American Journal of Primatology 74: 77-90.

Fimbel C (1994). The relative use of abandoned farm clearings and old forest habitats by primates and a forest antelope at Tiwai, Sierra Leone, West Africa. Biological Conservation 70: 277-286.

Guo S, Ji W, Li B, Li M (2008). Response of a group of Sichuan snub-nosed monkeys to commercial logging in the Qinling Mountains, China. Conservation Biology 22: 1055-1064. 
Hansen MC, Potapov PV, Moore R, Hancher M, Turubanova SA, Tyukavina A, Thau D, Stehman SV, Goetz SJ, Loveland TR, Kommareddy A, Egorov A, Chini L, Justice CO, Townshend JRG (2013). High-resolution global maps of 21st-century forest cover change. Science 342: 850-853.

Hassan MH (2001). Can Science Save Africa? Boston, American Association for the Advancement of Science.

Hayes LD, Carsten S (2017). Long-term field studies of mammals: what the short-term study cannot tell us. Journal of Mammology 98: 600-602.

Holl KD, Aide TM (2011). When and where to actively restore ecosystems? Forest Ecology and Management 261: 1558-1563.

IUCN (2018). The IUCN Red List of Threatened Species. Version 2018-1. http://www.iucnredlist.org.

Jacob AL, Lechowicz MJ, Chapman CA (2016). Non-native fruit trees facilitate colonization of native forest on abandoned farmland. Restoration Ecology 25: 211-219.

Jacob AL, Vaccaro I, Sengupta R, Hartter J, Chapman CA (2008). How can conservation biology best prepare for declining rural population and ecological homogenization? Tropical Conservation Science 1: 307-320.

Jacobson SK (2010). Effective primate conservation education: gaps and opportunities. American Journal of Primatology 72: 414-419.

Johns AD (1992). Vertebrate responses to selective logging: implications for the design of logging systems. Philosophical Transactions of the Royal Society of London Series B Biological Sciences 335: 437-442.

Kalbitzer U, Chapman CA (2018). Primate responses to changing environments in the Anthropocene. In Primate Life Histories, Sex Roles, and Adaptability - Essays in Honour of Linda M. Fedigan (Kalbitzer U, Jack KM, eds.), pp 283-310. New York, Springer.

Kirumira D, Baranga D, Hartter J, Valenta K, Tumwesigye C, Kagoro W, Chapman CA (2019). Evaluating a union between health care and conservation: a mobile clinic improves park-people relations, yet poaching increases. Conservation and Society 17: 51-62.

Kroeger A, Bakhtary H, Haupt F, Streck C (2017). Eliminating Deforestation from the Cocoa Supply Chain. Washington, World Bank.

Kühl HS, Arroyo-Rodríguez V, Boonratana R, Chapman CA, Chetry D, Cheyne SM, Cornejo FM, CortésOrtiz L, Cowlishaw G, Crockford C, de la Torre S, de Melo FR, Grüter C, Guzmán-Caro DC, Heymann EW, Herbinger I, Horwich RH, Ikemeh RA, Imong IS, Johnson S, Kappeler P, Kierulff CM, Koné I, Kormos R, Le Khac Q, Li B, Marshall AJ, Mittermeier RA, Orth L, Palacios E, Papworth SK, Plumptre A, Rawson BM, Petrovan SO, Refisch J, Roos C, Rylands AB, Setchell J, Smith R, Sop T, Schwitzer C, Slater K, Strum SC, Sutherland WJ, Talebi M, Wallis J, Wich S, Williamson L, Wittig RM, Junker J (Submitted). Severe lack of evidence limits effective conservation of the world's primates. Nature Ecology and Evolution.

Laestadius L, Maginnis S, Minnemeyer S, Potapov P, Saint-Laurent C, Sizer N (2011). Mapping opportunities for forest landscape restoration. Unasylva 238: 47-48.

Lammertink M, Nijman V, Setiorini U (2003). Population size, Red List status and conservation of the Natuna leaf monkey Presbytis natunae endemic to the island of Bunguran, Indonesia. Oryx 37: $472-479$.

Laurance WF, Sayer J, Cassman KG (2014). Agricultural expansion and its impacts on tropical nature. Trends in Ecology and Evolution 29: 107-116.

Lewis SL, Edwards DP, Galbraith D (2015). Increasing human dominance of tropical forests. Science 349: 827-832.

Li B, Li M, Li J, Fan P, Ni Q, Lu N, Zhou X, Long Y, Jiang Z, Zhang P, Huang Z, Hong C, Longjiang X, Pan R, Gouveia S, Dobrovolski R, Grueter CC, Oxnard C, Groves C, Estrada E, Garber PA (2018). The primate extinction crisis in China: Immediate challenges and a way forward. Biodiversity and Conservation 27: 3304-3327.

Linder JM (2013). African primate diversity threatened by "New Wave" of industrial oil palm expansion. African Primates 8: 25-38.

Marshall AJ, Meijaard E, Van Cleave E, Sheil D (2016). Charisma counts: the presence of great apes affects the allocation of research effort in the paleotropics. Frontiers in Ecology and the Environment 14: 13-19.

Meijaard E, Sheil D, Nasi R, Augeri D, Rosenbaum B, Iskandar D, Setyawati T, Lammertink M, Rachmatika I, Wong A, Shoehartono T, Stanley S, O’Brien T (2005). Life after Logging: Reconciling Wildlife Conservation and Production Forestry in Indonesian Borneo. Jakarta, Center for International Forestry Research.

Nahallage CAD, Huffman MA (2013). Macaque-human interactions in the past and present-day Sri Lanka. In The Macaque Connection, Cooperation and Conflict between Humans and Macaques (Radhakrishna S, Huffman MA, Sinha A, eds.), pp 135-148. New York, Springer.

Naughton-Treves L, Treves A, Chapman CA, Wrangham RW (1998). Temporal patterns of crop raiding by primates: linking food availability in croplands and adjacent forest. Journal of Applied Ecology 35: 596-606.

Primates Can Promote Forest Restoration

Folia Primatol 2020;91:669-687 
Oates JF, Struhsaker TT, McGraw WS (2016). Piliocolobus waldronae. In IUCN Red List of Threatened Species 2016. Gland, International Union for Conservation of Nature and Natural Resources (IUCN).

Omeja PA, Chapman CA, Obua J (2009). Enrichment planting does not promote native tropical tree restoration in a former pine plantation. African Journal of Ecology 47: 650-657.

Omeja PA, Chapman CA, Obua J, Lwanga JS, Jacob AL, Wanyama F, Mugenyi R (2011a). Intensive tree planting facilitates tropical forest biodiversity and biomass accumulation. Forest Ecology and Management 261: 703-709.

Omeja PA, Lawes MJ, Corriveau A, Valenta K, Sarkar D, Paim FP, Chapman CA (2016). Recovery of tree and mammal communities during large-scale forest regeneration in Kibale National Park, Uganda. Biotropica 48: 770-779.

Omeja PA, Lwanga JS, Obua J, Chapman CA (2011b). Fire control as a simple means of promoting tropical forest restoration. Tropical Conservation Science 4: 287-299.

Omeja PA, Obua J, Rwetsiba A, Chapman CA (2012). Biomass accumulation in tropical lands with different disturbance histories: contrasts within one landscape and across regions. Forest Ecology and Management 269: 293-300.

Osazuwa-Peters OL, Chapman CA, Zanne AE (2015). Selective logging: does the imprint remain on tree structure and composition after 45 years? Conservation Physiology 3: cov012.

Phalan B, Bertzky M, Butchart SHM, Donald PF, Scharlemann JPW, Stattersfield A, Balmford A (2013). Crop expansion and conservation priorities in tropical countries. PLoS One 8: e51759.

Pimm SL, Jenkins CN, Abell R, Brooks TM, Gittleman JL, Joppa LN, Raven PH, Roberts CM, Sexton JO (2014). The biodiversity of species and their rates of extinction, distribution, and protection. Science 344: 1246752

Polansky L, Boesch C (2013). Long-term changes in fruit phenology in a West African lowland tropical rain forest are not explained by rainfall. Biotropica 45: 434-440.

Potapov P, Hansen MC, Laestadius L, Turubanova S, Yaroshenko A, Thies C, Smith W, Zhuravleva I, Komarova A, Minnemeyer S (2017). The last frontiers of wilderness: tracking loss of intact forest landscapes from 2000 to 2013. Science Advances 3: e1600821.

Rothman JM, Chapman CA, Struhsaker TT, Raubenheimer D, Twinomugisha D, Waterman PG (2015). Long-term declines in nutritional quality of tropical leaves. Ecology 96: 873-878.

Schwitzer C, Mittermeier R, Johnson S, Donati G, Irwin M, Peacock H, Ratsimbazafy J, Razafindramanana J, Louis EE, Chikhi L (2014). Averting lemur extinctions amid Madagascar's political crisis. Science 343: $842-843$

Schwitzer C, Mittermeier RA, Rylands AB, Chiozza F, Williamson EA, Wallis J, Cotton A (2015). Primates in Peril: The World's 25 Most Endangered Primates 2014-2016. Arlington, Conservation International.

Simberloff D (1998). Flagships, umbrellas, and keystones: is single-species management passé in the landscape era? Biological Conservation 83: 247-257.

Stampone M, Hartter J, Chapman CA, Ryan SJ (2011). Trends and variability in localized precipitation around Kibale National Park, Western Uganda, Africa. Research Journal of Environmental and Earth Sciences 3: 14-23.

Steiper ME (2006). Population history, biogeography, and taxonomy of orangutans (genus: Pongo) based on a population genetic meta-analysis of multiple loci. Journal of Human Evolution 50: 509-522.

Strier KB (2010). Long-term field studies: positive impacts and unintended consequences. American Journal of Primatology 72: 772-778.

Strier KB, Possamai CB, Tabacow FP, Pissinatti A, Lanna AM, de Melo FR, Moreira L, Talebi M, Breves P, Mendes SL (2017). Demographic monitoring of wild muriqui populations: criteria for defining priority areas and monitoring intensity. PLoS One 12: e0188922.

Taubert F, Fischer R, Groeneveld J, Lehmann S, Müller MS, Rödig E, Wiegand T, Huth A (2018). Global patterns of tropical forest fragmentation. Nature 554: 519

Teferra D (2013). Funding higher education in Africa: state, trends and perspectives. Journal of Higher Education in Africa/Revue de l'enseignement supérieur en Afrique 11: 19-51.

Tsuji Y, Su H-H (2018). Macaques as seed dispersal agents in Asian forests: a review. International Journal of Primatology 39: 356-376.

UNESCO (2010). UNESCO Science Report 2010: The Current Status of Science around the World. Paris, UNESCO.

United Nations (2009). World Population Prospects. New York, United Nations.

United Nations Population Division (2008). World Urbanization Prospects: The 2007 Revision. New York, United Nations.

Vijay V, Pimm SL, Jenkins CN, Smith SJ (2016). The impacts of oil palm on recent deforestation and biodiversity loss. PLoS One 11: e0159668. 
Wheeler CE, Omeja PA, Chapman CA, Glipin M, Tumwesigye C, Lewis SL (2016). Carbon sequestration and biodiversity following 18 years of active tropical forest restoration. Forest Ecology and Management 373: 44-55.

Williams PH, Burgess ND, Rahbek C (2000). Flagship species, ecological complementarity and conserving the diversity of mammals and birds in sub-Saharan Africa. Animal Conservation 3: 249-260.

Wrangham R, Wilson M, Hare B, Wolfe ND (2000). Chimpanzee predation and the ecology of microbial exchange. Microbial Ecology in Health and Disease 12: 186-188.

Wright SJ, Calderón O (2018). Solar irradiance as the proximate cue for flowering in a tropical moist forest. Biotropica 50: 374-383.

Wright SJ, Muller-Landau HC (2006). The future of tropical forest species. Biotropica 38: 287-301.

Xiang Z, Yu Y, Yang M, Yang J, Niao M, Li M (2011). Does flagship species tourism benefit conservation? A case study of the golden snub-nosed monkey in Shennongjia National Nature Reserve. Chinese Science Bulletin 56: 2553-2558.

Yale School of Forestry (2018). Global Forest Atlas: Commercial Logging. New Haven, Yale School of Forestry, Yale University. 